\title{
PEMETAAN PERSEPSI INVESTOR ATAS INVESTASI REKSA DANA PUBLIK DENGAN METODE MULTIDIMENSIONAL SCALING
}

\author{
NURSETO ADHI* \\ DEWI BELLA SOKAWATI \\ UTAMI TRI SULISTYORINI \\ EDI WIJAYANTO \\ Politeknik Negeri Semarang \\ *nurseto.adhi@polines.ac.id
}

\begin{abstract}
This study aims to map the position of public mutual fund products and investment managers based on the results of perceptual mapping. The samples used in this study were 5 public mutual funds and 9 investment managers in each type of public mutual fund based on the investment portfolio selected using the purposive sampling method. The method of analysis used descriptive statistical analysis and multidimensional scaling. The results of the data processing of the mutual fund product attributes are processed in Microsoft Excel which further passed through the statistical test stage of multidimensional scaling ALSCAL (Alternative Least Square Scaling) using the SPSS application. The result of the multidimensional scaling test show that the perceptual mapping is divided into 4 quadrants based on the determinant attributes of public mutual fund products. It found that 6 mutual fund products divided by Risk and Costs determinant attributes, then 6 other mutual fund products found divided by NAB/UP and return, then 4 other mutual fund products found are not divided by determinant attributes and the rest 4 other mutual fund products divided by other determinant attribute in this research.
\end{abstract}

Keywords: perceptual mapping, mutual fund investment, and multidimensional scaling

Abstrak. Penelitian ini bertujuan untuk memetakan posisi pada produk reksa dana publik dan manajer investasi berdasarkan hasil perceptual mapping. Jumlah sampel yang digunakan dalam penelitian ini sebanyak 5 reksa dana publik dan 9 manajer investasi pada masing-masing jenis reksa dana publik didasarkan pada portofolio investasi yang dipilih berdasarkan metode purposive sampling. Metode analisis menggunakan analisis statistik deskriptif dan multidimensional scaling. Hasil pengolahan data atribut produk reksa dana diolah pada Microsoft Excel selanjutnya melewati tahap uji statistik multidimensional scaling ALSCAL (Alternatif Least Square Scaling) menggunakan bantuan aplikasi SPSS. Hasil uji multidimensional scaling menunjukkan bahwa pemetaan persepsi terbagi menjadi 4 kuadran berdasarkan pada atribut determinan dari produk reksa dana publik. 4 Kuadran tersebut ditemukan terdapat 6 reksadana yang dibedakan berdasarkan atribut determinan risiko dan biaya-biaya, kemudian 6 reksadana dibedakan Berdasarkan atribut determinan NAB/UP dan Return, lalu sebanyak 4 reksadana tidak dibedakan berdasarkan atribut determinan dan 4 reksadana dibedakan berdasarkan selain atribut determinan yang telah ditentukan.

Kata kunci. pemetaan persepsi, investasi reksa dana, dan multidimensional scaling

\section{PENDAHULUAN}

Investasi merupakan komitmen sejumlah dana untuk memperoleh keuntungan di masa datang (Tandelilin 2017: 101). Bentuk investasi yang dapat dilakukan yaitu dengan memilih investasi surat bernilai yang berbentuk kontrak tertulis berupa jangka pendek maupun jangka panjang. Investasi di pasar modal menjadi salah satu bentuk alternatif investasi yang mudah diakses dan sering digunakan masyarakat luas. Dengan adanya pasar modal, maka para pemilik modal yang ingin menginvestasikan dananya untuk jangka pendek maupun jangka panjang bisa memilih salah satu dari produk pasar modal. Menurut Lianti et al., (2017) biasanya calon investor akan mencari 
informasi terlebih dahulu mengenai instrumen investasi yang diinginkan. Akan tetapi, tidak semua calon investor memiliki waktu maupun dana untuk melakukan investasi, sehingga alternatif yang dapat digunakan adalah instrumen reksa dana yang diperjualbelikan di pasar modal. Berdasarkan Undang-Undang Pasar Modal No. 8 Tahun 1995 Pasal 1 Ayat 27, reksa dana adalah wadah yang digunakan untuk menghimpun dana dari masyarakat pemodal untuk selanjutnya diinvestasikan dalam portofolio efek oleh Manajer Investasi. Adapun reksa dana publik merupakan reksa dana yang diinvestasikan ke dalam portofolio efek seperti saham, obligasi, dan deposito yang telah dipublikasikan kepada masyarakat yang selanjutnya dikelola oleh manajer investasi.

Berdasarkan data statistik Otoritas Jasa Keuangan per Desember 2020, komposisi reksa dana publik yang paling besar diduduki oleh reksa dana saham dengan presentase $35,82 \%$ sedangkan reksa dana terprokteksi sebesar $26,04 \%$, reksa dana pendapatan tetap sebesar $20,65 \%$ dan reksa dana pasar uang sebesar $8,75 \%$ dari total NAB secara keseluruhan aset mencapai Rp 121.493.735.749.299,00. Hal ini menunjukkan bahwa diantara jenis reksa dana publik yang ada, reksa dana saham yang paling diminati oleh investor, sehingga memiliki kontribusi tertinggi atas pertumbuhan reksa dana publik. Permasalahannya adalah pada tahun 2020, kontribusi reksa dana saham mengalami penurunan seiring dengan penurunan total NABnya, dibandingkan jenis reksa dana publik yang lain, yang pada tahun 2020 mengalami peningkatan, seperti yang terlihat pada gambar di bawah ini:

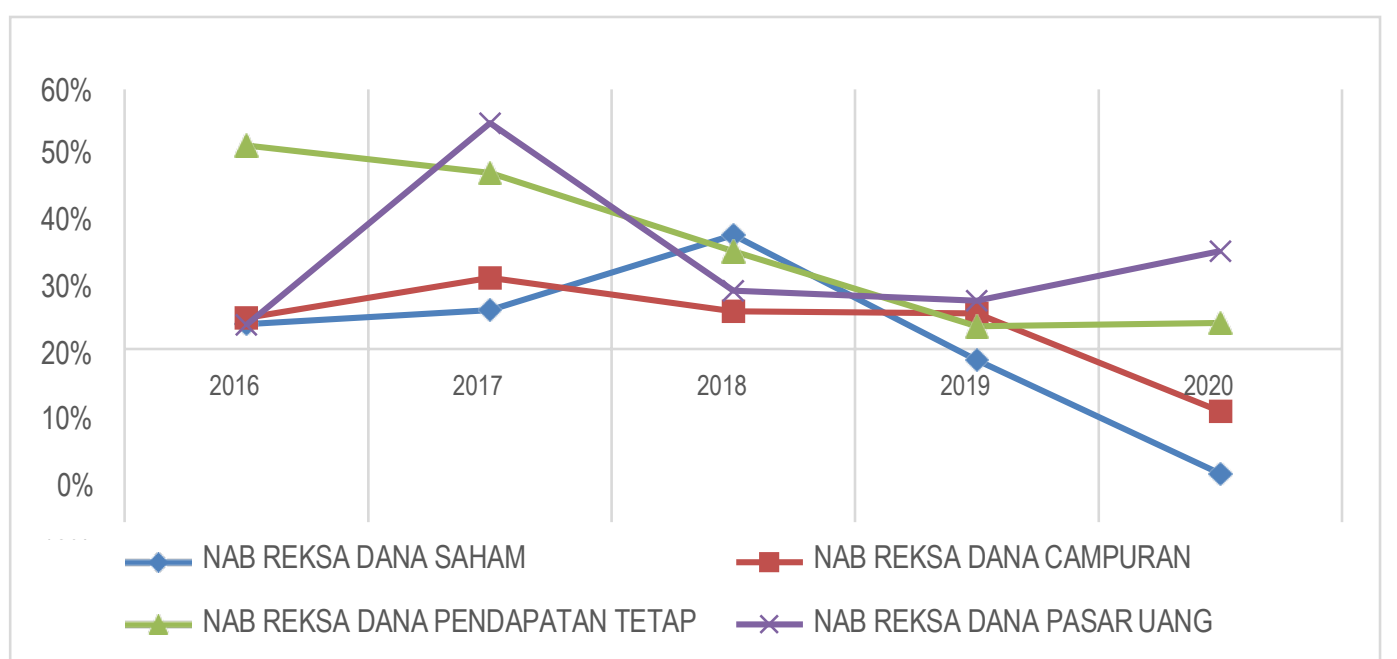

Sumber: www.ojk.go.id (data sekunder yang diolah), 2021

Gambar 1 Pertumbuhan Total NAB pada Jenis Reksa Dana Publik di Indonesia Tahun 2016-2020

Penurunan total NAB reksa dana publik saham ini, menunjukkan pergeseran peta persepsi investor atas investasi pada reksa dana, dari reksa dana publik saham ke reksa dana publik non saham. Oleh sebab itu sudah selayaknya bagi manajer investasi untuk memahami peta persepsi investor atas investasi reksa dana publik yang dikelolanya agar tidak salah mengambil kebijakan tentang jenis reksa dana yang akan diprioritaskan di pasar. Persepsi dapat menumbuhkan rasa suka ataupun tidak suka terhadap produk (Sulistyorini. 2017:32). Pada saat perusahaan menerbitkan suatu informasi tentang instrumen investasi reksa dana, investor akan memperoleh dan memproses informasi tersebut sehingga akan membentuk suatu persepsi atau perasaan suka ataupun tidak suka atas instrumen investasi reksa dana dimana mereka akan menginvestasikan dananya. Investor memiliki persepsi yang berbeda-beda atas informasi tentang instrumen investasi reksa dana publik yang diterbitkan. Hal ini disebabkan investor memiliki pengalaman dan pengetahuan yang berbeda-beda yang mereka jadikan dasar membangun persepsi mereka atas investasi reksa dana publik yang ada.

Ketika investor memetakan investasi reksa dana publik berdasarkan persepsinya, sebenarnya para investor membangun posisi investasi reksa dana publik di benak mereka berdasarkan pengetahuan dan pengalamannya terkait dengan atribut determinan investasi reksa dana publik tersebut. Dengan kata lain perceptual mapping of investors atau pemetaan persepsi investor merupakan metode yang digunakan investor untuk memetakan kesan relatif yang dirasakan terhadap sejumlah obyek yang dalam hal ini adalah investasi reksa dana publik berdasarkan kemiripan atribut determinan yang dimiliki oleh masing - masing jenis investasi reksa 
dana publik yang ditawarkan. Atribut determinan merupakan faktor-faktor yang dipertimbangkan investor dalam menentukan persepsi terhadap suatu investasi dan pada akhirnya memutuskan untuk menginvestasikan dananya pada instrumen investasi tersebut ataupun tidak menginvestasikan dananya (Shakeel \& Chaudhry, 2015).

Menurut Nahar (2016) salah satu metode yang bisa digunakan untuk menentukan posisi suatu obyek lainnya berdasarkan penilaian kemiripannya atau pemetaan persepsi adalah Multidimensional Scaling (MDS). Multidimensional Scaling (MDS) atau penskalaan dimensi ganda merupakan salah satu teknik multivariate dalam golongan interdependence technique yang digunakan untuk memetakan persepsi para responden secara visual dalam peta geometri. Peta geometri tersebut disebut spatial map atau perceptual map.

Analisis Multidimensional Scaling (MDS) berhubungan dengan pemetaan persepsi untuk menggambarkan posisi sebuah obyek dengan obyek lainnya berdasarkan dengan kemiripan (similarity) obyekobyek tersebut (Sumin, 2017). Pendekatan yang digunakan dalam Multidimensional Scaling (MDS) adalah similaritas (persepsi) yang dibagi menjadi dua yaitu similaritas non-atribut (persepsi langsung) dan similaritas atribut (persepsi tidak langsung). Pendekatan similaritas non-atribut (persepsi langsung) merupakan persepsi terhadap tingkat kemiripan antar stimulus tanpa terikat oleh atribut yang telah ditentukan. Hal ini memberikan kebebasan kepada investor terkait dengan persepsinya yang didasarkan pada fakta atau preferensi pribadi. Sedangkan pendekatan similaritas atribut (persepsi tidak langsung) merupakan persepsi terhadap tingkat kemiripan dengan atribut yang telah ditentukan (Shakeel \& Chaudhry, 2015).

Pergeseran peta persepsi investor atas investasi reksa dana publik saham ke non saham pada tahun 2020 , selayaknya menyadarkan para manajer investasi dan perusahaan bahwa pemahaman peta persepsi investor atas investasi reksa dana publik sangat diperlukan untuk menjaga agar perusahaan tetap dapat meraih dana berbiaya rendah. Salah satu metode yang dapat digunakan oleh manajer investasi ataupun perusahaan untuk memetakan persepsi investor ini adalah metode Multidimensional Scaling atau MDS. Oleh sebab itu sangat diperlukan penelitian yang terkait dengan pemetaan persepsi investor atas investasi reksa dana publik dengan metode Multidimensional Scaling sangat perlu untuk dilakukan

\section{TINJAUAN PUSTAKA \\ Persepsi Investor}

Persepsi merupakan pandangan individu dalam memahami obyek atau peristiwa melalui panca indera yang diperoleh dari pengalaman tentang obyek atau peristiwa dengan menyimpulkan informasi dan menafsirkan pesan. Persepsi bersifat subyektif dan situasional sehingga sangat mungkin memiliki perbedaan dengan persepsi individu lain terhadap obyek yang sama (Bening, 2018). Sedangkan menurut Schermerchon (2002) yang dikutip oleh Ulinnuha et al., (2020), persepsi merupakan proses dimana seseorang memilih, mengorganisir, menginterpretasikan dan merespon informasi dari dunia di sekitarnya. Seseorang dapat membentuk berbagai macam persepsi yang berbeda dari rangsangan yang sama.

Berdasarkan pendapat di atas, dapat disimpulkan bahwa persepsi merupakan cara pandang individu dalam memahami suatu objek melalui rangsangan yang diterima oleh panca indera berdasarkan pengalamanpengalaman yang ada sehingga menumbuhkan rasa suka ataupun tidak suka terhadap suatu objek. Maka dari itu, persepsi bersifat subyektif dan situasional sehingga sangat mungkin memiliki perbedaan antara persepsi investor satu dengan yang lain terhadap suatu instrumen investasi dalam menginvestasikan dana yang dimilikinya.

\section{Persepsi Investor atas Investasi Reksa Dana Publik}

Menurut Tandelilin (2007) reksa dana (mutual fund) adalah kegiatan menitipkan sejumlah dana pada perusahaan reksa dana, untuk digunakan sebagai modal investasi di pasar modal atau pasar uang. Sedangkan menurut Manurung (2010:3) reksa dana merupakan portofolio aset yang terdiversifikasi yang dijual kepada masyarakat dengan harga penawaran dengan nilai aktiva bersihnya. Reksa dana adalah wadah yang digunakan untuk menghimpun dana dari masyarakat pemodal untuk selanjutnya diinvestasikan dalam portofolio efek oleh manajer investasi (UU Pasar Modal No. 8 Tahun 1995 Pasal 1 Ayat 27). Adapun reksa dana publik merupakan reksa dana yang diinvestasikan ke dalam portofolio efek seperti saham, obligasi, dan deposito yang telah dipublikasikan kepada masyarakat yang selanjutnya dikelola oleh manajer investasi ke dalam bentuk reksa dana konvensional maupun syariah. 
Manajer investasi harus mampu memahami dan membangun rangsangan (stimuli) untuk merangsang investor membentuk persepsinya berdasarkan panca indera yang dimilikinya. Rangsangan ini terkait dengan investor yang ingin menginvestasikan dananya ke dalam suatu instrumen investasi, khususnya investasi reksa dana publik. Pada saat perusahaan menerbitkan suatu informasi tentang instrumen investasi reksa dana, investor akan memperoleh dan memproses informasi tersebut sehingga membentuk suatu persepsi atau perasaan suka ataupun tidak suka atas investasi reksa dana dimana mereka akan menginvestasikan dananya. Investor memiliki persepsi yang berbeda-beda atas informasi tentang instrumen investasi reksa dana publik yang diterbitkan. Hal ini disebabkan investor memiliki pengalaman dan pengetahuan yang berbeda-beda yang mereka jadikan dasar membangun persepsi mereka atas investasi reksa dana publik yang ada.

\section{Pemetaan Persepsi Investor dengan Metode Multidimensional Scaling}

Perceptual mapping of investors atau pemetaan persepsi investor merupakan metode yang digunakan investor untuk memetakan kesan relatif yang dirasakan terhadap sejumlah obyek yang dalam hal ini adalah investasi reksa dana publik berdasarkan kemiripan atribut determinan yang dimiliki oleh masing - masing jenis investasi reksa dana publik yang ditawarkan. Atribut determinan merupakan faktor-faktor yang dipertimbangkan investor dalam menentukan persepsi terhadap suatu investasi dan pada akhirnya memutuskan untuk menginvestasikan dananya pada instrumen investasi tersebut ataupun tidak menginvestasikan dananya (Shakeel \& Chaudhry, 2015). Salah satu metode yang bisa digunakan untuk menentukan posisi suatu obyek lainnya berdasarkan penilaian kemiripannya adalah Multidimensional Scaling. Multidimensional Scaling (MDS) merupakan salah satu teknik multivariate dalam golongan interdependence technique yang digunakan untuk memetakan persepsi para responden secara visual dalam peta geometri. Peta geometri tersebut disebut spatial map atau perceptual map (Nahar, 2016).

\section{Model Penelitian}

Berdasarkan landasan teori dari penelitian-penelitian terdahulu yang telah dilakukan, maka dikembangkan model pemikiran yang mendasari penelitian ini. Model pemikiran dapat dilihat pada Gambar 2 dibawah ini: Sumber: Hasil Olah Telaah Literatur

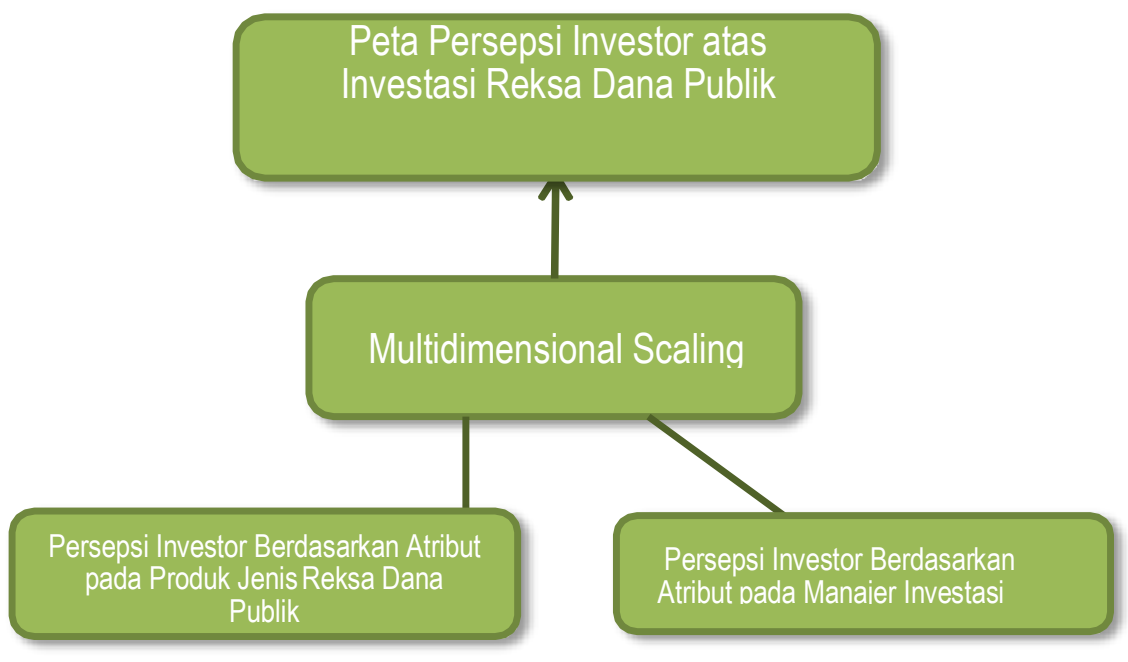

\section{METODE PENELITIAN}

Gambar 2 Model Penelitian

Penelitian merupakan ilmu pengetahuan yang digunakan untuk menemukan, mengembangkan kebenaran dalam suatu pengetahuan. Desain penelitian yang akan digunakan dalam penelitian ini yaitu penelitian kuantitatif terapan deskriptif mengenai pemetaan persepsi investor atas investasi reksa dana publik dengan metode multidimensional scaling.

\section{Populasi dan Sampel}

Populasi dalam penelitian ini adalah produk reksa dana publik yang memperoleh penyertaan efektif dari Otoritas Jasa Keuangan (OJK) selama periode penelitian, yaitu tahun 2020. Pengambilan sampel dalam penelitian ini menggunakan teknik nonprobability sampling dengan purposive sampling. Kriteria pemilihan sampel pada 
penelitian ini berdasarkan pada reksa dana publik yang memperoleh penyertaan efektif dari Otoritas Jasa Keuangan (OJK), reksa dana publik yang mempublikasikan Nilai Aktiva Bersih (NAB) dan Unit Penyertaan (UP), reksa dana publik yang berdasar pada portofolio investasinya yaitu reksa dana publik saham, reksa dana publik pendapatan tetap, reksa dana publik pasar uang dan reksa dana publik campuran, reksa dana yang mempublikasikan prospektus dan fund fact sheet, reksa dana publik yang memiliki performance atau kinerja terbaik berdasarkan beberapa situs transaksi reksa dana online seperti Bareksa dan Pasar Dana dengan sumber data dari Otoritas Jasa Keuangan (OJK). Berdasarkan kriteria tersebut didapatkan total 20 Reksadana yang terbagi menjadi 4 jenis yaitu Reksa dana Saham, Reksa Dana Campuran, Reksa Dana Pendapatan Tetap, dan Reksa Dana Pasar Uang yang masing-masing terdiri dari 5 Reksa dana.

\section{Metode Analisis Data}

Metode analisis data yang digunakan dalam penelitian berupa statistik deskriptif dan uji multidimensional scaling. Menurut Ghozali dan Ratmono (2013), statistik deskriptif yang dihasilkan dari data sekunder meliputi mean, median, minimum, maximum, dan standard deviation. Multidimensional Scaling (MDS) merupakan suatu teknik statistik yang mengukur obyek-obyek dalam ruangan multidimensional didasarkan pada penilaian responden mengenai kemiripan (similarity) obyek-obyek tersebut. Perbedaan persepsi diantara semua obyek direfleksikan didalam jarak relative diantara obyek-obyek tersebut didalam suatu ruangan multidimensional (Simamora, 2005). Beberapa tahapan analisis dalam melakukan analisis multidimensional scaling menurut Ginanjar (2008) adalah sebagai berikut:

a. Menghitung matriks jarak dengan menggunakan jarak Euclidean. Kedekatan antar objek pada perceptual map dapat dihitung dengan menggunakan jarak Euclidean antara objek pertama sampai dengan objek ke-j,

b. Mencari nilai eigen value dan eigen vector dengan rumusan sebagai berikut :

c. Membentuk koordinat objek berdasarkan vektor eigen $\mathrm{X}=\left[\begin{array}{ll}x_{1} & x_{2}\end{array}\right]$ kemudian selanjutnya menghitung $\mathrm{D}$ yang merupakan jarak Uclidean dari koordinat terbentuk.

d. Menghitung nilai stress dengan rumus sebagai berikut :

$$
S=\frac{\sum_{i=j}^{n}\left(d_{i j}-d_{i j}\right)^{2}}{\sum_{i=j}^{n} d_{i j}{ }^{2}}
$$

Nilai stress terbentuk dari hubungan monotonik antara kemiripan dan jarak akhir dengan ketentuan nilai seperti tabel berikut:

Tabel 1 Ketentuan Nilai Stress

\begin{tabular}{ccc}
\hline No. & Nilai Stress $(\%)$ & Goodness of Fit \\
\hline 1. & $>20$ & Buruk \\
2. & $10<$ stress $\leq 20$ & Cukup \\
3. & $5<$ stress $\leq 10$ & Baik \\
4. & $2.5<$ stress $\leq 5$ & Sangat Baik \\
5. & $0-2.5$ & Sempurna \\
\hline
\end{tabular}

Sumber : Ginanjar (2008)

Semakin kecil nilai stress menunjukkan bahwa hubungan monoton yang terbentuk antara ketidaksamaan dengan disparities semakin baik (didapat kesesuaian) dan kriteria peta persepsi (perceptual map) yang terbentuk semakin sempurna

\section{HASIL DAN PEMBAHASAN \\ Statistik Deskriptif}

Statistik deskriptif memberikan gambaran atau deskriptif data yang yang dihasilkan dari data sekunder meliputi mean, median, minimum, maximum, dan standard deviation. Hasil statistik deskriptif dapat dilihat pada tabel 2 sebagai berikut: 
Tabel 2 Hasil Statistik Deskriptif

\begin{tabular}{lrrrrr}
\hline & $\mathrm{N}$ & \multicolumn{1}{c}{ Minimum } & \multicolumn{1}{c}{ Maximum } & \multicolumn{1}{c}{ Mean } & \multicolumn{1}{c}{ Std. Deviation } \\
\hline NAB.UP & 20 & 982.77 & 4252.62 & 1639.2240 & 777.76301 \\
Return & 20 & 3.88 & 102.85 & 26.6190 & 25.07581 \\
Risk & 20 & .18 & 22.69 & 10.3065 & 9.08933 \\
Subscription.F & 20 & .00 & 2.00 & 1.2375 & .81707 \\
Redemption.F & 20 & .00 & 2.00 & 1.3000 & .83351 \\
Investment.Manager.F & 20 & .20 & 5.00 & 2.5975 & 1.07391 \\
\hline
\end{tabular}

Sumber: Hasil olah data menggunakan IBM SPSS Statistics (2021)

\section{Uji Multidimensional Scaling}

Dalam penelitian ini terdapat pemetaan 4 jenis produk reksa dana publik yang dipersepsikan oleh investor berdasarkan atribut dan manajer investasi yang dipersepsikan oleh investor berdasarkan atribut menggunakan uji multidimensional scaling.

Pemetaan Persepsi pada Produk Reksa Dana Publik Saham

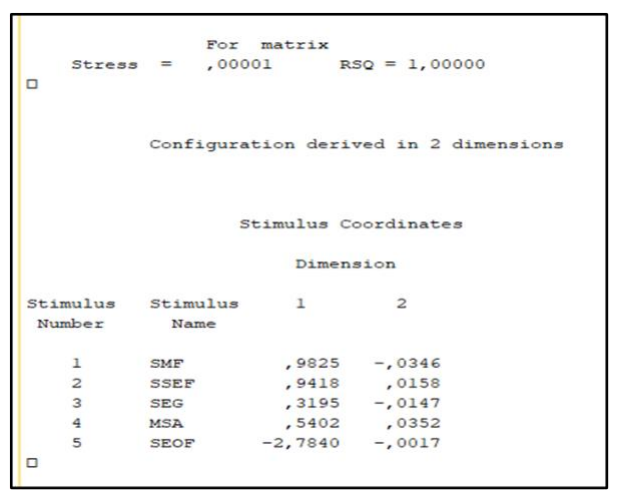

Sumber: Hasil olah data menggunakan IBM SPSS Statistics (2021)

Gambar 3 Stimulus Coordinates Produk Reksa Dana Publik Saham

Pada gambar 3 hasil pengujian menunjukan bahwa nilai stress sebesar 0,00001 dan nilai RSQ sebesar 1,00000. Berdasarkan garis pedoman kriteria nilai stress termasuk ke dalam sempurna dan nilai $R S Q>0,6$ dapat dikatakan bahwa model telah memenuhi kelayakan (Maholtra, 1999).

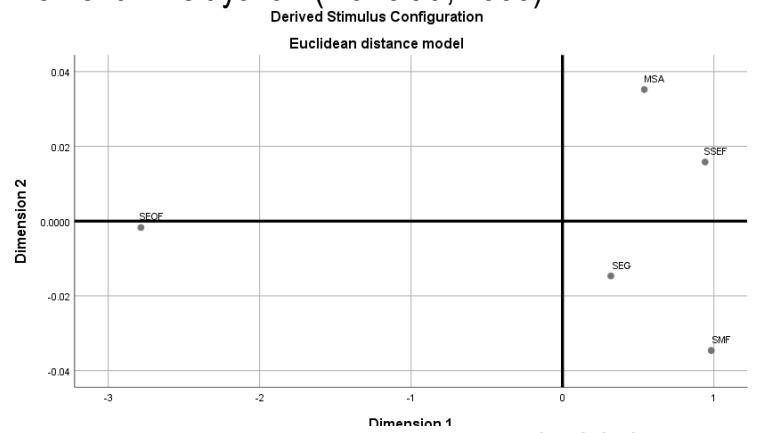

Sumber: Hasil olah data menggunakan IBM SPSS Statistics (2021)

Gambar 4 Perceptual Mapping Produk Reksa Dana Publik Saham

Pada gambar 4 menunjukan bahwa posisi dari 5 produk reksa dana publik saham berdasarkan atribut determinan (NAB/UP, return,risk, subscription fee, redemption fee dan investment manager fee) terdiri dari Sucorinvest Maxi Fund (SMF), Sucorinvest Sharia Equity Fund (SSEF), Shinhan Equity Growth (SEG), Manulife Saham Andalan (MSA) dan Syailendra Equity Opportunity Fund (SEOF). 


\section{Pemetaan Persepsi pada Produk Reksa Dana Publik Pendapatan Tetap}

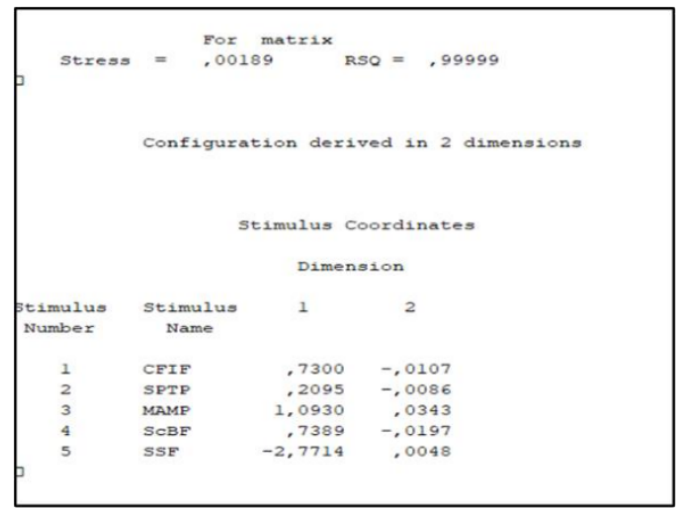

Sumber: Hasil olah data menggunakan IBM SPSS Statistics (2021)

Gambar 5 Stimulus Coordinates Produk Reksa Dana Publik Pendapatan Tetap

Pada gambar 5 hasil pengujian menunjukan bahwa nilai stress sebesar 0,00189 dan nilai RSQ sebesar 0,99999 . Berdasarkan garis pedoman kriteria nilai stress termasuk ke dalam sempurna dan nilai $R S Q>0,6$ dapat dikatakan bahwa model telah memenuhi kelayakan (Maholtra, 1999).

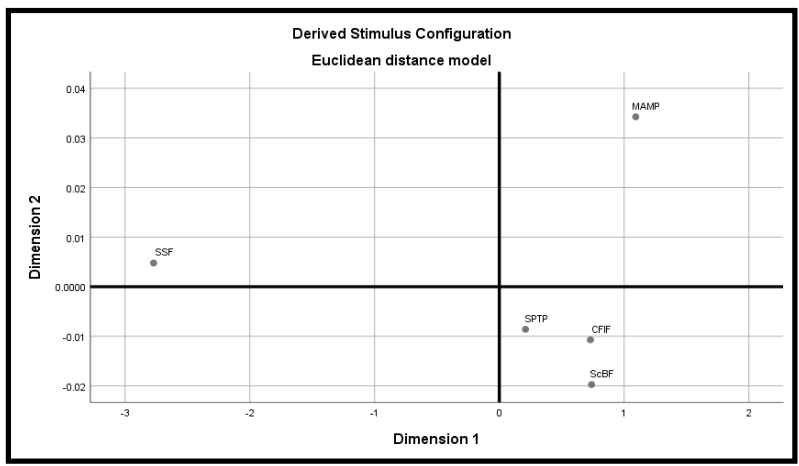

Sumber: Hasil olah data menggunakan IBM SPSS Statistics (2021)

Gambar 6 Perceptual Mapping Produk Reksa Dana Publik Pendapatan Tetap

Pada gambar 6 menunjukan bahwa posisi dari 5 produk reksa dana publik pendapatan tetap berdasarkan atribut determinan (NAB/UP, return,risk, subscription fee, redemption fee dan investment manager fee) terdiri dari Capital Fixed Income Fund (CFIF), Syailendra Pendapatan Tetap Premium (SPTP), Mega Asset Mantap Plus (MAMP), Sucorinvest Bond Fund (SoBF) dan Sucorinvest Stable Fund (SSF).

\section{Pemetaan Persepsi pada Produk Reksa Dana Publik Campuran}

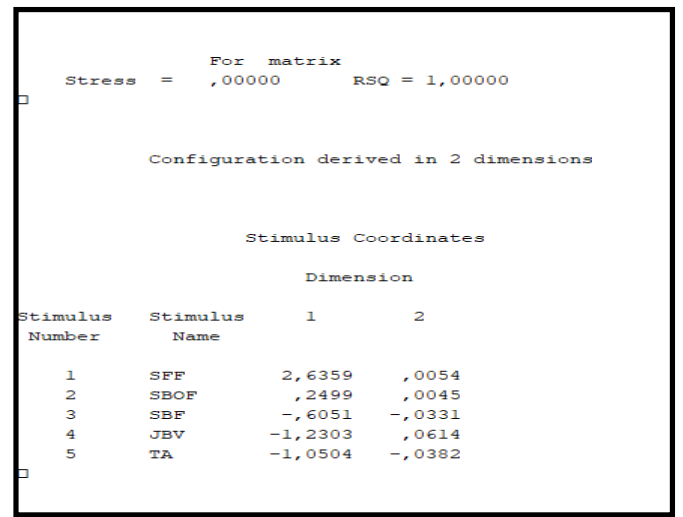

Sumber: Hasil olah data menggunakan IBM SPSS Statistics (2021) 
Gambar 7 Stimulus Coordinates Produk Reksa Dana Publik Campuran

Pada gambar 7 hasil pengujian menunjukan bahwa nilai stress sebesar 0,00000 dan nilai RSQ sebesar 1,00000. Berdasarkan garis pedoman kriteria nilai stress termasuk ke dalam sempurna dan nilai $R S Q>0,6$ dapat dikatakan bahwa model telah memenuhi kelayakan (Maholtra, 1999).

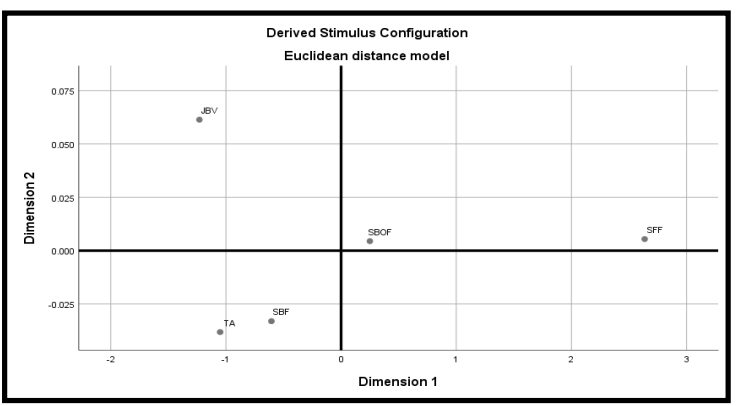

Sumber: Hasil olah data menggunakan IBM SPSS Statistics (2021)

Gambar 8 Perceptual Mapping Produk Reksa Dana Publik Campuran

Pada gambar 8 menunjukan bahwa posisi dari 5 produk reksa dana publik campuran berdasarkan atribut determinan (NAB/UP, return, risk, subscription fee, redemption fee dan investment manager fee) terdiri dari Sucorinvest Flexi Fund (SFF), Syailendra Balanced Opportunity Fund (SBOF), Shinhan Balance Fund (SBF), Jarvis Balanced Fund (JBF) dan TRAM Alpha (TA).

Pemetaan Persepsi pada Produk Reksa Dana Publik Pasar Uang

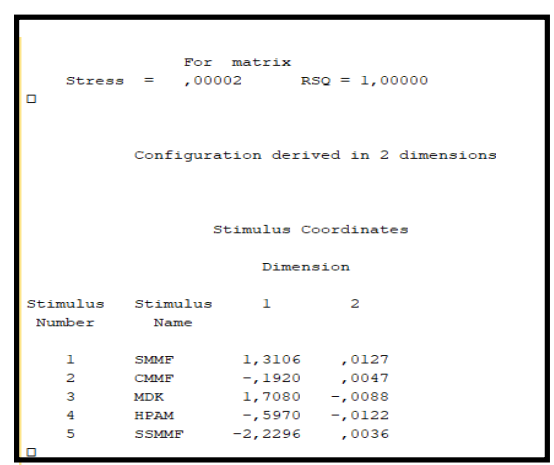

Sumber: Hasil olah data menggunakan IBM SPSS Statistics (2021)

Gambar 9 Stimulus Coordinates Produk Reksa Dana Publik Pasar Uang

Pada gambar 9 hasil pengujian menunjukan bahwa nilai stress sebesar 0,00002 dan nilai RSQ sebesar 1,00000. Berdasarkan garis pedoman kriteria nilai stress termasuk ke dalam sempurna dan nilai $R S Q>0,6$ dapat dikatakan bahwa model telah memenuhi kelayakan (Maholtra, 1999).

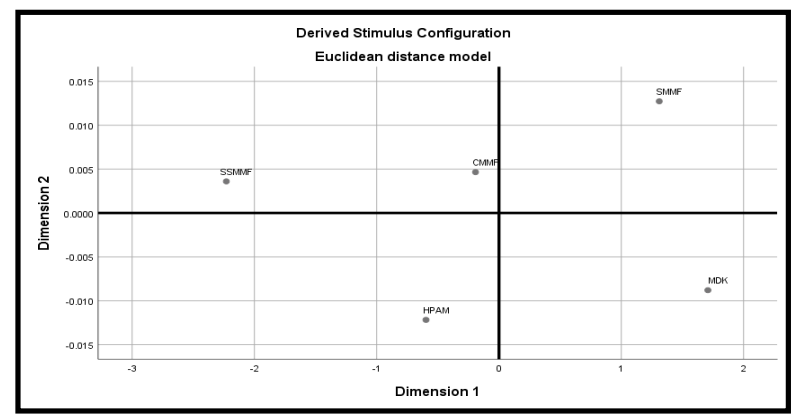

Sumber: Hasil olah data menggunakan IBM SPSS Statistics (2021)

Gambar 10 Perceptual Mapping Produk Reksa Dana Publik Pasar Uang 
Pada gambar 10 menunjukan bahwa posisi dari 5 produk reksa dana publik pasar uang berdasarkan atribut determinan (NAB/UP, return,risk, subscription fee, redemption fee dan investment manager fee) terdiri dari Sucorinvest Money Market Fund (SMMF), Capital Money Market Fund (CMMF), Manulife Dana Kas II Kelas A (MDK), HPAM Ultima Money Market (HPMA) dan Sucorinvest Sharia Money Market Fund (SSMMF).

\section{Pemetaan Persepsi pada Manajer Investasi}

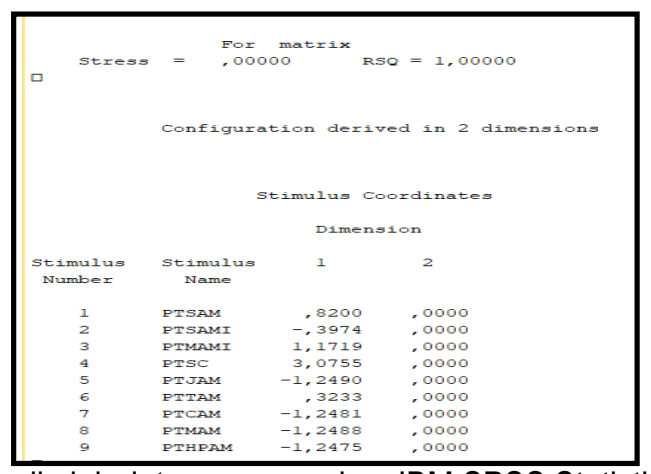

Sumber: Hasil olah data menggunakan IBM SPSS Statistics (2021)

Gambar 11 Stimulus Coordinates pada Manajer Investasi

Pada gambar 11 hasil pengujian menunjukan bahwa nilai stress sebesar 0,00000 dan nilai RSQ sebesar 1,00000. Berdasarkan garis pedoman kriteria nilai stress termasuk ke dalam sempurna dan nilai $R S Q>0,6$ dapat dikatakan bahwa model telah memenuhi kelayakan (Maholtra, 1999).

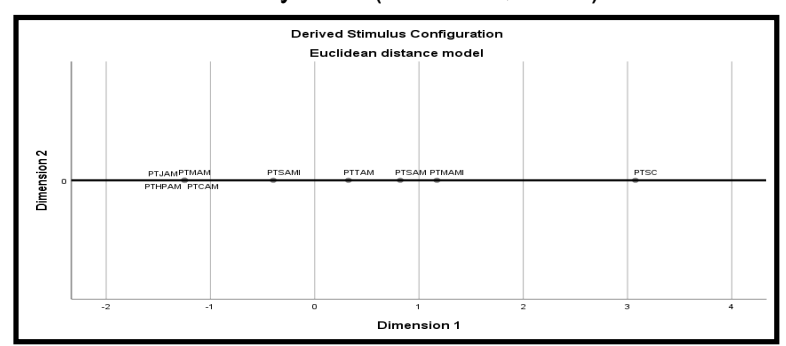

Sumber: Hasil olah data menggunakan IBM SPSS Statistics (2021)

Gambar 12 Perceptual Mapping pada Manajer Investasi

Pada gambar 12 menunjukan bahwa posisi dari 9 manajer investasi berdasarkan atribut determinan (total Asset Under Management (AUM) dan Unit) terdiri dari PT Sucorinvest Asset Management (PTSAM), PT Shinhan Asset Management Indonesia (PTSAMI), PT Manulife Aset Manajemen Indonesia (PTMAMI), PT Syailendra Capital (PTSC), PT Jarvis Aset Manajemen (PTJAM), PT Trimegah Asset Management (PTTAM), PT Capital Asset Management (PTCAM), PT Mega Asset Management (PTMAM) dan PT Henan Putihrai Asset Management (PTHPAM).

\section{Analisis Positioning Produk Reksa Dana Publik}

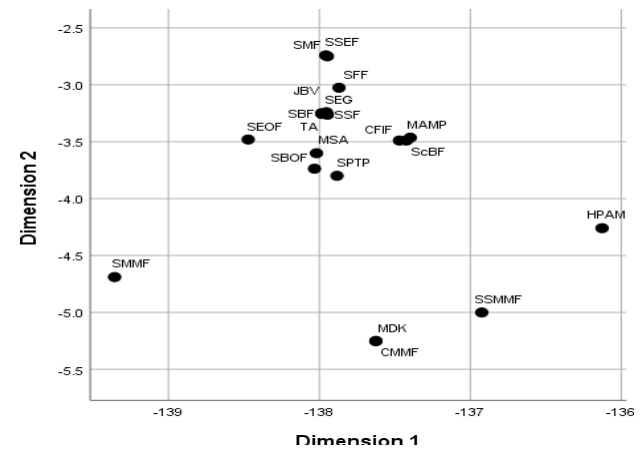

Sumber: Hasil olah data menggunakan IBM SPSS Statistics (2021)

Gambar 13 Image Positioning pada Produk Reksa Dana Publik 


\section{Interpretasi Hasil}

\section{Peta Persepsi Investor atas Investasi Reksa Dana Publik Berdasarkan Produk Reksa Dana Publik}

Produk reksa dana publik yang berada pada kuadran I dipersepsikan oleh investor dengan tidak membedakan atribut determinan pada produk reksa dana publik yang terdiri NAB/UP, return,risk, subscription fee, redemption fee dan investment manager fee dari masing-masing produk reksa dana publik. Produk reksa dana publik yang berada pada kuadran II dipersepsikan oleh investor dengan melihat atribut determinan berdasarkan NAB/UP dan return dari masing-masing produk reksa dana publik. Produk reksa dana publik yang berada pada kuadran III dipersepsikan oleh investor dengan melihat atribut determinan berdasarkan risiko dan biaya-biaya seperti subscription fee, redemption fee dan investment manager fee dari masing-masing produk reksa dana publik. Produk reksa dana publik yang berada pada kuadran IV dipersepsikan oleh investor dengan melihat selain atribut determinan yang telah ditentukan. Rekapitulasi Hasil akan tampak pada tabel berikut:

Tabel 3 Peta Persepsi Investor atas Produk Reksa Dana Publik

\begin{tabular}{|c|c|c|}
\hline $\begin{array}{l}\text { Perusahaan Pengelola } \\
\text { Reksa Dana }\end{array}$ & Produk Reksa Dana & $\begin{array}{c}\text { Peta Persepsi Investor } \\
\text { (Membedakan/tidak membedakan) }\end{array}$ \\
\hline \multirow[t]{5}{*}{$\begin{array}{l}\text { PT Sucorinvest Asset } \\
\text { Management }\end{array}$} & Sucorinvest Maxi Fund & $\begin{array}{l}\text { Berdasarkan atribut determinan risiko dan biaya- } \\
\text { biaya }\end{array}$ \\
\hline & $\begin{array}{l}\text { Sucorinvest Sharia Equity Fund } \\
\text { Sucorinvest Flexi Fund } \\
\text { Sucorinvest Bond Fund }\end{array}$ & $\begin{array}{l}\text { Berdasarkan atribut determinan NAB/UP dan Return } \\
\text { Berdasarkan atribut determinan NAB/UP dan Return } \\
\text { Berdasarkan atribut determinan risiko dan biaya- } \\
\text { biaya }\end{array}$ \\
\hline & Sucorinvest Stable Fund & Tidak membedakan atribut determinan \\
\hline & $\begin{array}{l}\text { Sucorinvest Money Market } \\
\text { Fund }\end{array}$ & Berdasarkan atribut determinan NAB/UP dan Return \\
\hline & $\begin{array}{l}\text { Sucorinvest Sharia Money } \\
\text { Market Fund }\end{array}$ & Tidak membedakan atribut determinan \\
\hline \multirow[t]{2}{*}{$\begin{array}{l}\text { PT Shinhan Asset } \\
\text { Management Indonesia }\end{array}$} & Shinhan Equity Growth & $\begin{array}{l}\text { Berdasarkan atribut determinan risiko dan biaya- } \\
\text { biaya }\end{array}$ \\
\hline & Shinhan Balance Fund & Selain atribut determinan yang telah ditentukan \\
\hline PT Manulife Aset & Manulife Saham Andalan & Berdasarkan atribut determinan NAB/UP dan Return \\
\hline Manajemen Indonesia & Manulife Dana Kas II Kelas A & $\begin{array}{l}\text { Berdasarkan atribut determinan risiko dan biaya- } \\
\text { biaya }\end{array}$ \\
\hline \multirow[t]{3}{*}{ PT Syailendra Capital } & $\begin{array}{l}\text { Syailendra Equity Opportunity } \\
\text { Fund }\end{array}$ & Selain atribut determinan yang telah ditentukan \\
\hline & $\begin{array}{l}\text { Syailendra Balanced } \\
\text { Opportunity Fund }\end{array}$ & Berdasarkan atribut determinan NAB/UP dan Return \\
\hline & $\begin{array}{l}\text { Syailendra Pendapatan Tetap } \\
\text { Premium }\end{array}$ & $\begin{array}{l}\text { Berdasarkan atribut determinan risiko dan biaya- } \\
\text { biaya }\end{array}$ \\
\hline $\begin{array}{l}\text { PT Jarvis Aset } \\
\text { Manajemen }\end{array}$ & Jarvis Balanced Fund & Tidak membedakan atribut determinan \\
\hline $\begin{array}{l}\text { PT Trimegah Asset } \\
\text { Management }\end{array}$ & TRAM Alpha & Selain atribut determinan yang telah ditentukan \\
\hline \multirow[t]{2}{*}{$\begin{array}{l}\text { PT Capital Asset } \\
\text { Management }\end{array}$} & Capital Fixed Income Fund & $\begin{array}{l}\text { Berdasarkan atribut determinan risiko dan biaya- } \\
\text { biaya }\end{array}$ \\
\hline & Capital Money Market Fund & Tidak membedakan atribut determinan \\
\hline $\begin{array}{l}\text { PT Mega Asset } \\
\text { Management }\end{array}$ & Mega Asset Mantap Plus & Berdasarkan atribut determinan NAB/UP dan Return \\
\hline $\begin{array}{l}\text { PT Henan Putihrai Asset } \\
\text { Management }\end{array}$ & HPAM Ultima Money Market & Selain atribut determinan yang telah ditentukan \\
\hline
\end{tabular}




\section{Peta Persepsi Investor atas Investasi Reksa Dana Publik Berdasarkan Manajer Investasi}

Kelompok yang memiliki total AUM kurang dari Rp 100.000.000.000.000 terdiri dari PT Jarvis Aset Manajemen (PTJAM), PT Mega Asset Management (PTMAM), PT Henan Putihrai Asset Management (PTHPAM) dan PT Capital Asset Management (PTCAM). Kelompok yang memiliki total AUM diantara Rp 50.000.000.000.000.000 - Rp 100.000.000.000.000.000 terdiri dari PT Sucorinvest Asset Management (PTSAM), PT Shinhan Asset Management Indonesia (PTSAMI), PT Manulife Aset Manajemen Indonesia (PTMAMI) dan PT Trimegah Asset Management (PTTAM). Kelompok yang memiliki total AUM lebih dari Rp 100.000.000.000.000.000 terdiri PT Syailendra Capital (PTSC).

\section{KESIMPULAN}

Penelitian ini menemukan bahwa pada peta persepsi investor berdasarkan produk reksadana publik, terdapat 6 reksadana yang dibedakan berdasarkan atribut determinan risiko dan biaya-biaya, kemudian 6 reksadana dibedakan Berdasarkan atribut determinan NAB/UP dan Return, lalu sebanyak 4 reksadana tidak dibedakan berdasarkan atribut determinan dan 4 reksadana dibedakan berdasarkan selain atribut determinan yang telah ditentukan. hal ini menunjukkan bahwa mayoritas investor membedakan reksadana berdasarkan risiko, biayabiaya yang ada, NAB/UP dan return dalam memilih berinvestasi pada reksadana. Penelitian ini juga menemukan bahwa pada peta persepsi investor berdasarkan manajer investasi reksadana publik, terdapat 4 Manajer investasi yang dibedakan Berdasarkan atribut total AUM (Asset Under Management) kurang dari Rp 100.000.000.000.000, kemdian 4 Manajer investasi yang dibedakan Berdasarkan atribut total AUM (Asset Under Management) di antara Rp 50.000.000.000.000 - Rp 100.000.000.000.000, dan 1 manajer investasi yang dibedakan Berdasarkan atribut total AUM (Asset Under Management) lebih dari Rp 100.000.000.000.000.

\section{Saran}

Penelitian ini memperoleh bukti analisis data yang dapat direkomendasikan sebagai implikasi (masukan) sesuai prioritas untuk manajemen perusahaan yang mengelola reksa dana, yaitu perusahaan yang telah mendapat izin sebagai Manajer Investasi. Sumbangan hasil penelitian yang dapat diberikan kepada perusahan-perusahan dijelaskan sebagai berikut: Apabila atribut determinan berdasarkan NAB/UP dan return, maka fokus utama yang dilakukan oleh perusahaan pengelola reksa dana adalah melakukan strategi yang efektif dalam mengelola produk reksa dana agar mendapat keuntungan atau return sesuai yang diharapkan. Perubahan NAB/UP disebabkan oleh perubahan kondisi harga pasar. Apabila atribut determinan berdasarkan risiko dan biaya-biaya, maka fokus utama yang dilakukan oleh perusahaan pengelola reksa dana adalah menekan risiko dan biaya-biaya tersebut. Semakin kecil risiko dan biaya-biaya dalam suatu produk reksa dana mencerminkan bahwa manajer investasi dalam mengelola reksa dana untuk investor lebih efisien.

\section{Keterbatasan Penelitian}

Objek penelitian yang digunakan dalam penelitian ini sangat terbatas, hanya terdiri dari 5 produk reksa dana publik pada masing-masing jenis reksa dana publik yang didasarkan pada portofolio investasi dan 9 perusahaan reksa dana yang terdaftar di Otoritas Jasa Keuangan pada periode 2020. Atribut determinan lainnya yang belum dipertimbangkan pada produk reksa dana. Dalam penelitian ini, hanya terdiri dari NAB/UP, return, risiko, subscription fee, redemption fee dan investment manager fee. Penelitian berikutnya dapat dapat menggunanakan data primer, kemudian disarankan untuk mempertimbangkan atribut determinan lainnya selain atribut yang telah digunakan serta melakukan uji yang dapat digunakan untuk memetakan persepsi berdasarkan kemiripan selain dari atribut determinan. Uji yang dapat dilakukan yaitu Uji Algoritma K-Means Clustering.

\section{DAFTAR PUSTAKA}

Bening, A. (2018). Pengaruh Pengetahuan Investor, Persepsi Risiko Dan Motivasi Terhadap Keputusan Investasi Saham Syariah (Studi Kasus Pada Investor Mahasiswa Fakultas Ekonomi Dan Bisnis Islam UIN Walisongo Semarang). Skripsi. Semarang : Universitas Islam Negeri Walisongo.

Darmadji, T dan Fakhrudin. (2006). Pasar Modal di Indonesia Pendekatan Tanya Jawab. Jakarta: Salemba Empat. 
Fahmi, K. M. (2019). Pengaruh Pengetahuan Generasi Z, Persepsi, dan Fasilitas Perbankan Syariah Terhadap Preferensi Pada Bank Syariah dengan Sikap Sebagai Variabel Intervening. Skripsi. Jakarta : Universitas Islam Negeri Syarif Hidayatullah.

Ginanjar, Irlandia, (2008). Aplikasi Multidimensional Scaling Untuk Memposisikan Produk Pada Masalah Produk Existing. Surabaya: Fakultas Sains dan Teknologi Universitas Airlangga.

Ghozali, Imam., Dwi Ratmono. 2013. Analisis Multivariat dan Ekonometrika, Teori, Konsep, dan Aplikasi dengan Eviews 8. Semarang: Badan Penerbit Universitas Diponegoro.

Hsieh, H. P., Tebourbi, I., Lu, W. M., \& Liu, N. Y. (2020). Mutual fund performance: The decision quality and capital magnet efficiencies. Managerial and Decision Economics, 41(5), 861-872.

Lianti, A., \& Nurul R. (2017). Analisis Perbandingan Kinerja Reksa Dana Saham Syariah dengan Reksa Dana Saham Konvensional di Indonesia. Jurnal Ekonomi Dan Bisnis, 18(2), 141-153

Manurung, Adler H. (2010). Berinvestasi, Pendirian, dan Pembubaran Reksa dana, Jakarta : PT Adler Manurung Press.

Masruroh, Aini. (2014). Konsep Dasar Investasi Reksa dana. Jurnal Sosial dan Budaya Syar-I, 1(1), 83-96.

Mubeen, S., \& Jaggaiah, T. (2018). Perception Of Indian Women Investor Towards Investment In Mutual Funds. $3(1), 64-69$.

Nahar, J. (2016). Penerapan Metode Multidimensional Scaling Dalam Pemetaan Sarana Kesehatan Di Jawa Barat. Jurnal Matematika Integratif, 12(1), 43-49.

Nazir, Mohammad. (2011). Metode Penelitian. Bogor: Penerbit Ghalia Indonesia

Prasongko, H. A. (2020). Persepsi Dan Minat Masyarakat Terhadap Investasi Pada Instrumen Keuangan (Studi Kasus Galeri Investasi Di Kota Metro). Skripsi. Metro: Institut Agama Islam Negeri. Rapista, W. (2013). Analysis Multidimensional Scaling (Studi Kasus : Persepsi Dan Preferensi Mahasiswa Terhadap Mata Kuliah Pada Jurusan Matematika Fakultas Matematika Dan IImu Pengetahuan Alamuniversitas Bengkulu. GRADIEN: Jurnal IImiah MIPA, 53(9), 1689-1699.

Raja, M., B, J., \& Ph.D. (2020). Investors 'Perceptions Towards Mutual Fund Schemes Investment - A Study With Special Reference To Chennai City. 11(5), 299-306.

Sachdeva, M. S., Bhatia, M. M., \& Kalra, M. R. (2013). Behavioural Effect of Mutual Fund Investor's and Perception in Millenium City. Pacific Business Review International, 5(11), 89-97.

Shakeel, M., \& Chaudhry, S. (2013). Attribute Based Preference \& Predictability Of Mutual Funds for Investment by Investment Professionals: A Study From Emerging Market. European Journal of Innovative Business Management, 1, 17-26.

Shakeel, M., \& Chaudhry, S. (2015). Attribute-Based Perceptual Mapping Of Mutual Fund Schemes : A Study From An Emerging Market. International Journal Economics And Business Research, 10(1), 81-103.

Sharma, N. (2012). Indian Investor's Perception towards Mutual Funds. Business Management Dynamics, 2(2), $1-9$.

Simamora, B. (2005). Analisis Mulivariat Pemasaran Edisi Pertama. Jakarta: PT. Gramedia Pustaka Utama.

Singh, B. K. (2012). A study on investors ' attitude towards mutual funds as an investment option. International Journal of Research in Management, 61-70.

Sugiyono. (2014). Metode Penelitian Pendidikan Pendekatan Kuantitatif, Kualitatif, dan R\&D. Bandung: Alfabeta

Sulistyorini, Utami Tri. (2017). Metode Penelitian Analisis Kausal-Regresi. Semarang: Politeknik Negeri Semarang.

Sumin. (2017). Penerapan Analisis Multidimensional Scaling untuk Memetakan Persepsi Stakeholders Terhadap Mutu Lulusan lain Pontianak. Jurnal Pemikiran Pendidikan Islam Journal, 11(2), 97-104.

Tandelilin, E. (2017). Pasar Modal: Manajemen Portofolio dan Investasi. Yogyakarta: PT Kanisius.

Ulinnuha, M., Susilowati, D. E., \& Hana, K. F. (2020). Persepsi Investor Pemula Terhadap Pembelian Saham Syariah di Indonesia. Jurnal IImu Ekonomi Dan Bisnis slam, 2(1), 1-14.

Umar, Husein. (2013). Metode Penelitian untuk Skripsi dan Tesis Bisnis Edisi Kedua. Jakarta: Rajawali Pers

www. sikapiuangmu.ojk.go.id, diakses pada tanggal 28 April 2021

www.reksadana.ojk.go.id, diakses pada tanggal 30 Juni 2021

www.pasardana.id, diakses pada tanggal 30 Juni 2021

www. bareksa.com, diakses pada tanggal 30 Juni 2021 